\title{
Identification of Water Vapour Transmission Rate (WVTR) of Aluminum Foil Packaging Barrier using The Gravimetric Testing Method
}

\author{
Syafira ${ }^{1}$, Supardianningsih ${ }^{1}$, dan Mawan Nugraha ${ }^{1 *}$ \\ 1Politenik Negri Media Kreatif, Jakarta \\ E-mail: firalydrus@gmail.com, supardianningsih@polimedia.ac.id, \\ manoegra@gmail.com
}

\begin{abstract}
The packaging is the most important thing for packing the food product. The main function of packaging is protecting the product from external factors such as light, water vapour, oxygen, and humidity. Sometimes the damage of food products occurs because of the contaminations of water vapour like a clumping on powdered food products. However, aluminum foil is a good barrier to protect food products. The packaging barrier needs to be tested to assure which one is the best to protect food products, especially from water vapour. Water vapour transmission rates are used to test how much the vapour can be absorbed by the packaging and the test results can be used as a reference for product packaging. The identification of water vapour transmission absorbed on the aluminum foil is tested using the gravimetric testing method and refers to the ASTM E96 standard. The result shows the thicker aluminum foil has used to protect the food products, the lower they absorb water vapour.
\end{abstract}

Keywords: water vapour transmission rates, packaging barrier, aluminum foil, gravimetric

\section{Identifikasi Laju Transmisi Uap Air pada Barrier Kemasan Aluminium Foil Menggunakan Metode Pengujian Gravimetri}

\begin{abstract}
ABSTRAK
Kemasan merupakan bagian terpenting dalam mengemas produk pangan. Fungsi utama kemasan adalah sebagai pelindung produk dari faktor eksternal seperti cahaya, uap air, oksigen, dan kelembaban. Beberapa produk pangan ditemukan mengalami kerusakan karena terkontaminasi oleh uap air seperti terjadinya penggumpalan pada produk pangan bertekstur bubuk. Aluminium foil merupakan barrier kemasan yang baik dalam melindungi produk pangan. Barrier kemasan ini perlu diuji untuk memastikan sifat perlindungan bahan kemasan terutama terhadap uap air. Pengujian laju transmisi uap air digunakan sebagai suatu bentuk pengujian untuk mengetahui jumlah uap air yang dapat terserap oleh sebuah kemasan, yang mana data tersebut dapat menjadi tolak ukur dalam sistem pengemasan sebuah produk. Kandungan uap air yang diidentifikasi terserap pada aluminium foil diukur melalui pengujian dengan metode gravimetri yang disesuaikan dengan standar ASTM E96. Hasil penelitian menunjukkan bahwa semakin


tebal aluminium foil yang digunakan sebagai barrier kemasan, maka semakin rendah kemampuan bahan tersebut dalam mentransmisikan uap air.

Kata kunci: laju transmisi uap air, barrier kemasan, aluminium foil, gravimetri

\section{A. LATAR BELAKANG}

Kemasan dapat diartikan sebagai pembungkus atau pengepak. Dalam artian lain, kemasan diartikan sebagai suatu alat atau wadah untuk melindungi produk dari berbagai faktor eksternal yang dapat mempengaruhi produk yang ada di dalamnya (Soroka, 1996). Kemasan merupakan suatu kesatuan yang tidak dapat dipisahkan dari bagian suatu produk (Julianti, 2014).

Kemasan dapat dibuat dari berbagai macam bahan. jenis-jenis kemasan berdasarkan bahan pembuatnya yaitu kemasan kertas dan karton, kemasan plastik, kemasan logam, serta kemasan kaca (Julianti, 2016). Meski demikian, dalam kondisi tertentu diperlukan barrier atau lapisan tambahan untuk mendukung bahan utama kemasan agar kemasan yang digunakan nantinya dapat melindungi produk dengan sebaik-baiknya.

Barrier atau lapisan penahan pada kemasan merupakan suatu kesatuan yang memiliki peranan penting. Salah satu fungsi dari barrier adalah untuk menahan udara, uap air, dan debu masuk ke dalam produk. Barrier kemasan yang baik adalah barrier yang paling sesuai dengan produk dan dapat melindungi produk secara utuh. Oleh karena itu penentuan barrier kemasan perlu disesuaikan dengan kebutuhan produk, jenis produk yang akan dikemas dan, juga suhu penyimpanannya. Terdapat banyak jenis barrier yang dapat digunakan sebagai lapisan pada kemasan, misalnya plastik berjenis nylon, PE (polypropylene) ataupun material bahan lainnya seperti metalized film atau aluminium foil (Klimchuk dan Krasovec, 2006).

Aluminium foil adalah salah satu bahan barrier yang baik dalam melindungi produk. Sifatnya yang tahan terhadap tembusan cahaya juga udara menjadi salah satu alasan mengapa bahan ini baik dalam melindungi produk. Aluminium foil juga ramah terhadap lingkungan karena menghasilkan sedikit limbah ketika didaur ulang. Penggunaan aluminium foil juga memiliki kekurangan. Jika terjadi kerusakan sedikit saja pada lembaran aluminium foil, hal ini akan merusak kemasan tersebut dan mempengaruhi isi produk yang dikemas. Dengan demikian semakin baik lapisan/barrier yang digunakan, maka akan semakin baik pula kemasan tersebut menahan faktor eksternal yang dapat masuk mengontaminasi produk. (Kaihatu, 2014)

Sebagai suatu contoh pada produk pangan bertekstur bubuk akan mengalami penggumpalan karena terkontaminasi oleh udara luar, oksigen, dan uap air yang masuk ke dalam produk meski belum kadaluarsa. Hal tersebut menunjukkan bahwa adanya perpindahan zat uap air dari luar kemasan ke dalam produk yang 
tidak kasat mata lalu merusak produk yang ada di dalamnya. (Yuyun dan Delli, 2011).

Pada dasarnya setiap bahan kemasan memiliki kemampuan menyerap uap air (adsorpsi), demikian juga dengan barrier aluminium foil yang rentan terhadap kerusakan yang memungkinkan adanya celah untuk dipengaruhi oleh faktor eksternal berupa uap air, maka dari itu kualitas dari lembaran aluminium foil tersebut juga harus diperhatikan untuk meminimalisir kerusakan yang terjadi pada produk yang akan dikemas nantinya (Khopkar, 1990). Oleh karena itu, keberadaan uap air yang masuk melewati bahan kemasan menjadi faktor penting yang harus diteliti terkait dengan kualitas bahan tersebut. Untuk menjamin kualitas bahan kemasan tersebut dari pengaruh uap air yang dapat masuk melewati kemasan, perlu dilakukan pengujian terlebih dahulu melalui pengujian laju transmisi uap air. Berdasarkan hal tersebut penulis bermaksud melakukan penelitian "Identifikasi Laju Transmisi Uap Air pada Barrier Kemasan Aluminium Foil Menggunakan Metode Pengujian Gravimetri".

\section{B. METODE PENELITIAN}

Penelitian ini dilakukan di Laboratorium Pengujian Balai Besar Kimia Kemasan, Jakarta. Sampel berupa aluminium foil dengan beberapa ketebalan, selanjutnya dilakukan pengujian ketebalan dan uji laju transmisi uap air/water vapour transmission rate (WVTR).

\section{HASIL DAN PEMBAHASAN}

\section{Pengaruh Ketebalan Aluminium Foil Terhadap Hasil Uji}

Berdasarkan hasil dari pengujian laju transmisi uap air yang telah dilakukan di laboratorium Balai Besar Kimia Kemasan selama 5 hari dengan keadaan suhu dan kelembaban yang terkontrol, maka didapatkan nilai dari hasil laju transmisi uap air barrier kemasan aluminium foil dengan 3 ketebalan yang berbeda seperti ditunjukkan Tabel 1 dan Gambar 1.

Berdasarkan data hasil uji ketebalan bahan, dapat disimpulkan bahwa ketebalan dari bahan barrier kemasan aluminium foil berpengaruh pada hasil uji nilai laju transmisi uap air. Hal tersebut dibuktikan dengan hasil pengujian yang telah dilakukan dan dari grafik yang ada, yaitu pergerakan uap air akan semakin rendah diikuti dengan ketebalan contoh uji lembaran aluminium foil yang semakin tebal.

Tabel 1. Perbandingan Data Hasil Uji dengan Ketebalan Bahan

\begin{tabular}{|c|c|c|c|}
\hline No & Contoh uji & $\begin{array}{c}\text { Tebal } \\
\text { Bahan }\end{array}$ & $\begin{array}{c}\text { Hasil uji } \\
\text { WVTR }\end{array}$ \\
\hline 1 & $\begin{array}{c}\text { Aluminium } \\
\text { Foil A }\end{array}$ & $\begin{array}{c}0,075 \\
\mathrm{~mm}\end{array}$ & $\begin{array}{c}0,3135 \\
\mathrm{~g} / \mathrm{m}^{2} / 24 \mathrm{ja} \\
\mathrm{m}\end{array}$ \\
\hline 2 & $\begin{array}{c}\text { Aluminium } \\
\text { Foil B }\end{array}$ & $\begin{array}{c}0,081 \\
\mathrm{~mm}\end{array}$ & $\begin{array}{c}0,1506 \\
\mathrm{~g} / \mathrm{m}^{2} / 24 \mathrm{ja} \\
\mathrm{m}\end{array}$ \\
\hline 3 & $\begin{array}{c}\text { Aluminium } \\
\text { Foil C }\end{array}$ & $\begin{array}{c}0,071 \\
\mathrm{~mm}\end{array}$ & $\begin{array}{c}0,3517 \\
\mathrm{~g} / \mathrm{m}^{2} / 24 \mathrm{ja} \\
\mathrm{m}\end{array}$ \\
\hline
\end{tabular}

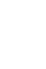




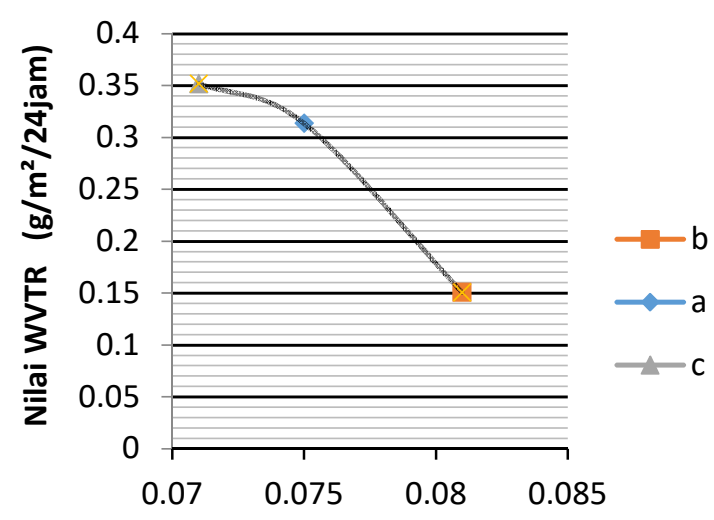

Ketebalan Aluminium Foil (mm)

Gambar 1. Grafik Perbandingan Data Hasil Uji dengan Ketebalan Bahan Uji

Hasil pengujian di atas menunjukkan bahwa lembaran aluminium foil B memiliki ketebalan yang paling tinggi yaitu sebesar 0,081 $\mathrm{mm}$ dengan hasil nilai laju transmisi uap air yang paling rendah sebanyak 0,1506 g/ m²/24jam. Pada urutan kedua ditunjukkan pada contoh uji aluminium foil A yaitu memiliki ketebalan 0,075 mm dengan nilai laju transmisi uap air sebanyak 0,3135 $\mathrm{g} / \mathrm{m}^{2} / 24 \mathrm{jam}$, dan pada urutan terakhir dengan ketebalan yang paling rendah yaitu pada lembaran aluminium foil contoh uji $\mathrm{C}$ dengan ketebalan 0,071 $\mathrm{mm}$ dengan nilai laju transmisi uap air yang paling tinggi yaitu sebanyak 0,3517 $\mathrm{g} / \mathrm{m}^{2} / 24$ jam uap air yang dapat masuk ke dalam lembaran aluminium foil tersebut.

Pengaruh ketebalan bahan uji aluminium foil terhadap nilai laju transmisi uap air dapat disimpulkan bahwa semakin tipis aluminium foil, maka semakin tinggi pula kekasaran permukaannya, atau dengan kata lain semakin rentannya kekuatan barrier aluminium foil tersebut. Sehingga kemampuan adsorpsi (penyerapan) terhadap uap air semakin tinggi. Itulah sebabnya transmisi uap air pada aluminium foil dengan tebal $0.081 \mathrm{~mm}$ memiliki angka paling rendah, disusul ketebalan $0.075 \mathrm{~mm}$ dan terendah pada ketebalan $0.071 \mathrm{~mm}$.

\section{Identifikasi Aluminium Foil Yang Paling Baik Sebagai Barrier Kemasan}

Berdasarkan hasil dari ilustrasi Gambar 1 tentang grafik perbandingan data hasil uji dengan ketebalan bahan uji pengujian laju transmisi uap air menunjukkan adanya pergerakan transmisi uap air yang semakin rendah terhadap contoh uji terhadap barrier/lembaran aluminium foil yang semakin tebal.

Berdasarkan hasil data pengujian laju transmisi uap air yang telah dilakukan tersebut, didapatkan hasil berupa nilai yang dapat dijadikan acuan untuk mengidentifikasi barrier aluminium foil yang paling baik untuk digunakan dari hasil uji tersebut, yaitu lembaran aluminium foil contoh uji B yang memiliki nilai laju transmisi uap air paling rendah dibandingkan dengan 2 contoh uji lainnya. Walaupun menurut Krochta dkk. dalam Dwimayasanti (2016), berdasarkan Japan Industrial Standart disebutkan bahwa batas maksimal nilai laju transmisi uap air adalah sebesar 10 $\mathrm{g} / \mathrm{m}^{2}$, yang mengartikan bahwa semua contoh uji aluminium foil dapat diterima sebagai bahan kemas yang baik dan masih memenuhi kriteria standar maksimal yang ditentukan oleh JIS. 


Namun berdasarkan hasil $\begin{aligned} & \text { pengujian tesebut dapat dikatakan } \\ & \text { bahwa ketebalan aluminium foil }\end{aligned}$
$\begin{aligned} & \text { tersebut dapat dikatakan bahwa } \\ & \text { aluminium foil B dikategorikan sebagai } \\ & \text { tersebut memiliki pengaruh terhadap }\end{aligned}$
barrier yang paling baik karena
kemasan dengan nilai laju transmisi
aap yasil pengujian laju transmisi uap
mempengaruhi produk yang dikemas
dengannya untuk lebih awet dengan
panjang.

\section{SIMPULAN}

Proses pengujian laju transmisi uap air dilakukan dengan menggunakan metode gravimetri yang mengacu pada standar ASTM E96 yang digunakan untuk mengetahui laju pergerakan uap air dari setiap contoh bahan uji aluminium foil. Dalam pengujian ini, pengambilan data dilakukan pada rentang waktu 5 hari dengan keadaan suhu dan kelembaban yang terkontrol.

Berdasarkan hasil pengujian laju transmisi uap air didapatkan hasil yang bervariasi dari 3 contoh uji dengan ketebalan yang berbeda yaitu contoh uji A (tebal 0,075 mm) memberikan nilai WVTR sebesar 0,3135 $\mathrm{g} / \mathrm{m}^{2} / 24$ jam, contoh uji B $(0,081 \mathrm{~mm})$ sebesar $0,1506 \mathrm{~g} / \mathrm{m}^{2} / 24 \mathrm{jam}$, dan contoh uji C $(0,071 \mathrm{~mm})$ sebesar 0,3517 $\mathrm{g} / \mathrm{m}^{2} / 24$ jam. Berdasarkan data hasil

\section{E. DAFTAR PUSTAKA}

Dwimayasanti, Rany. 2016. Pemanfaatan karagenan sebagai edible film. Jurnal Oseana. VOL XLI (2): 8-19.

Julianti, Sri. 2014. The Art Of Packaging. Jakarta: PT Gramedia Pustaka Utama.

Julianti, Sri. 2017. A Practical Guide To Flexible Packaging. Jakarta: PT Gramedia Pustaka Utama.

Kaihatu, Thomas. 2014. Manajemen Pengemasan. Yogyakarta: CV Andi Offset

Khopkar. 1990. Konsep Dasar Kimia Analitik. Jakarta: UI Press.

Klimchuk, M. dan Krasovec, S. A. 2006. 
Desain Kemasan, Jakarta:

Erlangga.

Nugraheni, Mutiara. 2018. Kemasan

Pangan. Yogyakarta: Plantaxia.

Soroka, Walter. 1996. Fundamental Of

Packaging Technology. United Kingdom (Uk): The Institue Of

Packaging.

Yuyun, A. dan Gunarsa, Delli. 2011.

Cerdas Mengemas Produk

Makanan dan Minuman, Jakarta

Selatan: PT AgroMedia Pustaka. 